\title{
THE STRATEGIES OF REFUSING REQUESTS BY STUDENTS OF DIFFERENT ETHNIC GROUPS
}

\author{
Arsen Nahum Pasaribu, Erika Sinambela, Tiara K. Pasaribu, Jubil Ezer Sihite, \\ dan Rony Arahta Sembiring
}

Faculty of Language and Arts,Universitas HKBP Nommensen, Medan, Indonesia

Email: arsen.pasaribu@uhn.ac.id, erikasinambela@uhn.ac.id, tiarakristina@uhn.ac.id, jubilezer.sihite@uhn.ac.id, dan ronyarahta.sembiring@uhn.ac.id

\begin{abstract}
This study investigated the strategies used by students of different ethnic groups (Batak, Javanese, and Malay) in refusing requests. A total of 30 participants were involved in this research. Each ethnic group was represented by 10 students that came from three different universities in Medan, Indonesia. Discourse Completion Test (DCT) was used to collect the data. Data were analyzed by using refusal categorization. The results showed that the participants preferred to use indirect refusal strategies to respond to lecturer's requests, and followed by direct and adjunct strategies respectively. This study also indicated that Batak students performed refusal acts more direct than any other Javanese or Malay students. Meanwhile Javanese students tend to employ refusals more indirect compared to any other students. The Malay students performed the acts moderately. The results indicated that the refusal strategies used by the students of three different cultural backgrounds might be influenced by their cultural circumstances. Future studies should be undertaken to investigate the phenomena in different research settings with more participants to be involved.
\end{abstract}

Keywords: refusal strategies; different ethnic group; request; speech acts.

Coresponden Author

Email: arsen.pasaribu@uhn.ac.id Artikel dengan akses terbuka dibawah lisensi

\section{Introduction}

The study of refusal strategy in social communication has shown a growing number for last few decades. The application of speech acts in communication by speakers in any social situation is meant to meet the goals of their communication as categorized by (Searle \& Searle, 1977) comprising of commissives, declarations, directives, expressives, representatives, and more particularly acts like apologies, requests, complains and refusals (Kasper \& Rose, 2001). Refusals are face-threatening acts (Brown, Levinson, \& Levinson, 1987) and belong to the category of commissives because they commit the refuse to (not) performing an action (Searle \& Searle, 1977). 
In social interaction, people are expected to keep the communication running well. They endeavor to avoid saying "no" to invitation, suggestion, offer, request, proposal, and appeals. Therefore, in order to minimize the hurt feeling over the refusal, they seek to find "proper ways" to be likely accepted by the interlocutors. Choosing strategy to refuse a request, for example, may be varied in different individuals and cultures. Moreover, refusal acts can be realized verbally or non-verbally, like shaking our head spontaneously.

The act of refuse may occur in all languages. However, the way of refusal is different in every language. (Beebe, Takahashi, \& Uliss-Weltz, 1990) asserted that the differences may exist in the frequency of occurrence, the context of use, and linguistic features that were varied according to culture. In a similar vein, (Rubin, 1980) affirmed that speech acts are much influenced by a culture of society. The way of people from different culture to say "no" is interesting to investigate as the way they act to refuse may be diverse from culture to culture.

The research in refusal strategies, according to cultural basis, is mainly divided in two categories: the refusals of a single language or culture and the refusals of across different cultures or languages (Morkus, 2014). Several studies have been conducted to examine the refusal acts in single or multi-cultures or languages. ( $\mathrm{Su}, 2020)$ and (Lee, 2016) investigated the relation of power to refusal strategies used by Chinese students. $\mathrm{Su}$ investigated the use of genuine and superficial refusals among medical students responding to invitation and offering, while Lee explored the use, form, order, and contents of refusals by Cantonese learners of English. Both research revealed that mandarin students performed varied strategies refusals when responding to invitation offers. Genuine refusal, in the Su's case is often delayed and mitigated while superficial refusal is frequently directly projected. (Solihah \& Imperiani, 2020) investigated different strategies in refusal by Sundanese students of different gender. This study confirms that both gender have no significant difference in practicing strategies in refusal acts. (Harared, 2020), moreover, examined the refusal strategies used in comedy. The research showed that direct refusal was dominantly used in all situation of the communication. In addition, (Musniati, 2019) also had interest in investigating the strategies to refuse by a taxi driver when serving the passenger in Lombok. This study claimed that both direct and indirect strategies were used by the taxi driver when responding to his taxi passengers' order or requests.

The research in refusal strategies by a cross-culture people and language attract some scholars to investigate. (Moafian, Yazdi, \& Sarani, 2019) explored the refusal of request speech act in Persian, English, and Blauchi languages. This investigation revealed the significant differences in frequency of using direct, indirect, and adjunct strategies by the people in three languages. (Ismail, 2017), moreover, scrutinized the different ways of Malay and Spanish students to refuse. This research indicated that there were significant differences in frequency and method of refusal acts by the students of both different cultures. In the similar vein, (Shishavan \& Sharifian, 2016) and (Shishavan \& Sharifian, 2016) studied the refusal strategies by learners of Iranian English language and Anglo-Australian language. The research exposed that the power of interlocutors influenced the refusal strategies used by the students.

The previous research had similar in common that the focus and scope of the studies were around the refusal strategies by people in single culture investigation or multi-cultural investigation by different countries. However, the research on refusal strategies by multi-cultural ethnic group in a country, such as in Indonesia context is 
relatively unexplored. Accordingly, this study attempted to explore the refusal strategies used by several university students in Medan that come from three different ethnic groups: Batak, Javanese, and Malay.

\section{Methodology}

A total of 30 participants were involved in this research. They originated in three different ethnic groups: 10 students of Batak (BS), 10 students of Malay (MS) and 10 students of Javanese (JS). All participants were students of different universities in Medan, North Sumatra, Indonesia.

Data were collected by using a written Discourse Completion Test (DCT). The DCT was constructed in requests with five different situations. The requests were written in Indonesian Language as most of participants were unable to speak in English. The DCT was created in Google forms and sent to the participants. The five scenarios of the request can be seen in the following.

\section{Request 1}

Lecturer: Bisakah kamu datang ke kantor saya jam 8 pagi besok? Ada hal yang ingin saya bicarakan dengan kamu. (Can you come to my office at 8 o'clock tomorrow morning? I have something to discuss with you.)

Students:

Request 2

Lecturer: Tolong bawakan buku ibu ke kantor, bawaan ibu sangat berat. (Please take my books to my office, my stuffs are too heavy to take myself.)

Student:

Request 3

Lecturer: Tolong dibantu teman nya dalam menyelesaikan soal yang saya berikan kemarin. (Please help your friend to answer the questions I gave yesterday).

Student:

Request 4

Lecturer : Tolong kirimkan paket ini ke pengiriman sore ini, saya tidak waktu ke sana. (Please send this package to the courier agent this afternoon, I have no time to go there).

Student:

Request 5

Lecturer: Tolong kamu pinjamkan buku dengan judul ini ke perpustakaan untuk ibu. (Please borrow this book with this title to the library for me).

Student:

The procedures of data collection were undertaken in following steps.

1. Creating five requests.

2. The scenario was set that students must refuse all the requests

3. The DCT was sent to the students by using Google form.

4. Students were demanded to complete the DCT in 3 days.

The completed forms of DCT were analysed by (Beebe et al., 1990) categorisation of refusal strategies. The refusal act was analysed according to the sub-categories: direct, indirect, and adjunct. The analysis of data was classified in number and percentage according to the students by different ethnic groups. The results of data 
Arsen Nahum Pasaribu,Erika Sinambela,Tiara K. Pasaribu,Jubil Ezer Sihite,Rony Arahta Sembiring

analysis were input in a table that showed the number of refusal occurrences in each category and the most dominant occurrences in whole refusal studies.

\section{Results and Discussion}

Overall, a total of 165 refusal strategies were produced by the students as the responses to five requests. The data were analyzed by using (Beebe et al., 1990) categorization of refusal strategies. The strategies can be seen in the forms of direct, indirect, and adjunct.

Table 1

The frequency and percentage of refusal acts by students of three different ethnic groups

\begin{tabular}{cccccc}
\hline Refusal Strategies & & Students & \multicolumn{2}{c}{ Total } \\
\hline & Batak & Javanese & Malay & F & $\%$ \\
\hline
\end{tabular}

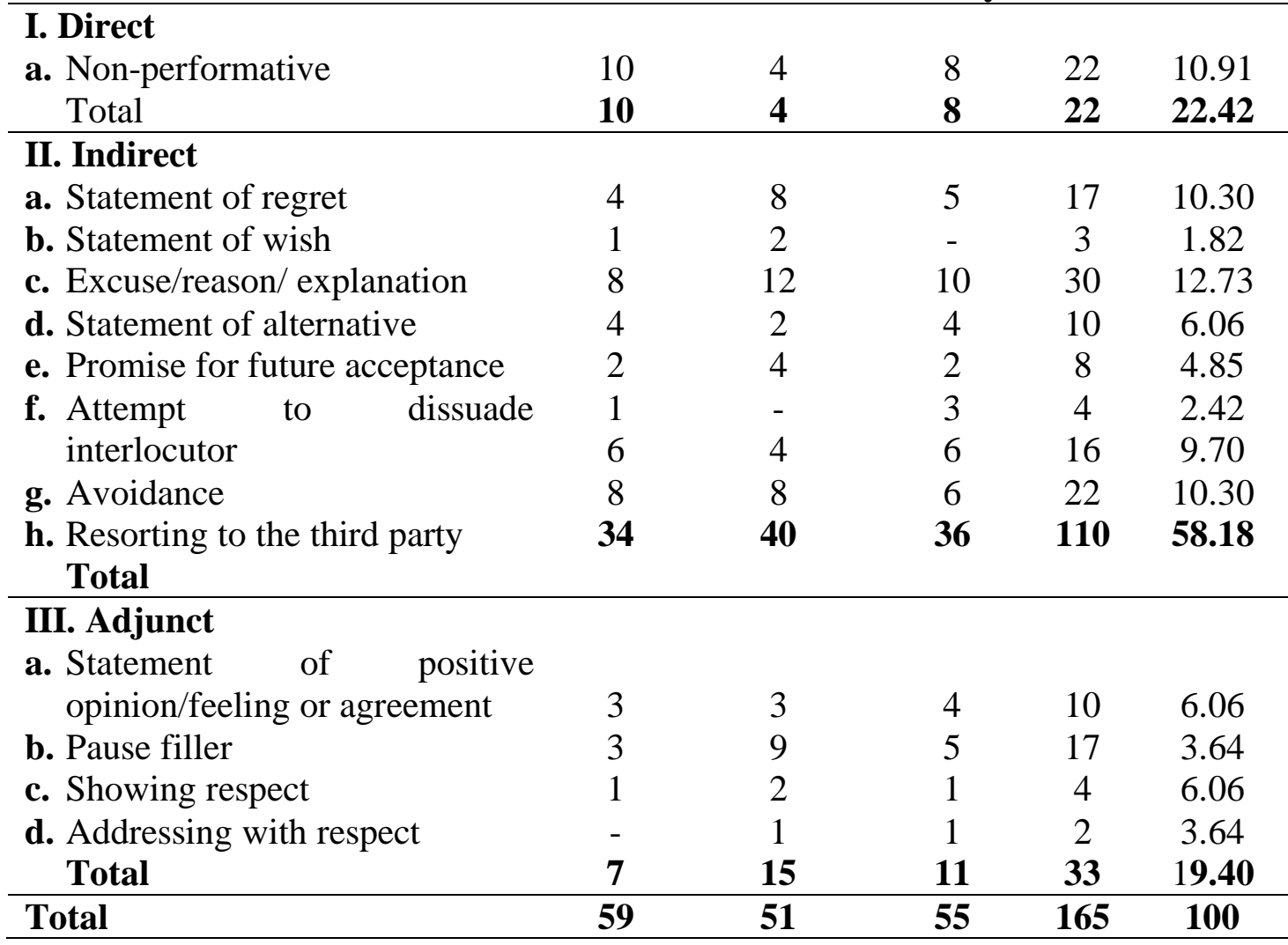

Table 1 indicates a total of 165 refusal acts were employed by students of different ethnic groups in Medan. Generally, the refusal strategies were dominated by indirect strategies $(58.18 \%)$, and then followed by direct $(22.42 \%)$ and adjunct refusals $(19.40 \%)$. JS most dominantly used indirect strategies, which is $34(20.61 \%)$. On the other hand, BS and MS expressed 31 (18.79\%) indirect strategies respectively. The most dominant strategy used in indirect refusal was excuse/reason/explanation, 21 $(12.73 \%)$. In direct refusal strategies, BS mostly used direct strategies with 19 occurrences, followed by MS and JS with 11 and 7 occurrences respectively. In adjunct, it was represented by 32 refusal strategies (19.40\%). MS employed strategies most dominantly with 13 occurrences, and followed by JS with 10 strategies, and BS with 9 strategies. The refusals analysis by BS, JS, and MS are explained. 
The findings showed that the strategies used by the students to refuse the lecturer's requests were varied. The different acts of refusal were determined by the diverse cultural backgrounds of the students as asserted by (Beebe et al., 1990) and (Rubin, 1980). More specific findings of the research uncovered that the students from the three different ethnic groups have different ways of expressing refusal to the requests by the lecturer. The method of BS to refuse the requests was more direct than more direct compared to JS and MS. It explains that the culture and characteristics of Batak people that speak straight forward. On the other hand, the students of Javanese background employed the refusal acts to the requests were more indirect than any other students of BS and MS. This result may appear as the consequence of the cultural background of JS that tend to be indirect in the way of communication. In the meantime, MS was relatively moderate in performing the refusal acts to the requests.

The results are in line with the studies by (Musniati, 2019) that confirmed that Indonesian people like other asian countries tend to produce indirect method of refusal to save the face of the interlocutors. However, in certain cases of refusal acts by some ethnic group in Indonesia, like Batak, tend to perform more direct if compared to any other ethnic groups in Indonesia. This study also showed power played big roles to influence the interlocutors when expressing refusals (Lee, 2016). Power seems more influential than cultural background to deploy strategies when refusing to the requests. This claim can be proved by the ways of BS, that are culturally more direct in conversation, performed the refusal acts relatively indirect to the lecturer's requests.

\section{Conclusion}

Social interactions need social rules in practice in order to avoid akwardness or even dislike of the interlocutors. Most of the rules are unwritten, but real in social communication. Being polite in conversation is one of examples of the rules in social communication. Refusal to request, invitation, or suggestion is considered being rude. Thus, people seek to deploy strategies of being polite when having conversation, especial when refusing to requests. The strategies of refusal are much influenced by the cultural background. Several studies have shown evidence to this claim. As some scholars asserted that most Asian people tend to perfom inderectly to refuse a request. This study was designed to confirm the previous findings. Students from three diffrent ethnic groups : Batak, Javanese, and Malay were studied to find the ways they perfomed refusal acts to several reguests by a lecturer. Discourse completion test was deployed to collect the data. Using refusal catefories by (Beebe et al., 1990) the data analysis was perfomed. The study finally reveal that cultural background of the interlocutors influenced the ways of they expressed the refusal strategies. However, the power of the interlocutors is likely more influential that cultural background. 
Arsen Nahum Pasaribu,Erika Sinambela,Tiara K. Pasaribu,Jubil Ezer Sihite,Rony Arahta Sembiring

\section{REFERENCES}

Beebe, Leslie M., Takahashi, Tomoko, \& Uliss-Weltz, Robin. (1990). Pragmatic transfer in ESL refusals. Developing Communicative Competence in a Second Language, 5573.

Brown, Penelope, Levinson, Stephen C., \& Levinson, Stephen C. (1987). Politeness: Some universals in language usage (Vol. 4). Cambridge university press.

Harared, Nico. (2020). Investigating Refusal Strategies in Situational Comedy: A Case Study of Sheldon Cooper, $\mathrm{Ph}$. D. 4th International Conference on Arts Language and Culture (ICALC 2019), 477-485. Atlantis Press.

Ismail, R. .. (2017). The difference of speech act of refusal strategies between the Malays and Spanish. Cross-Cultural Studies. The Social Sciences, 12, 1334-1343.

Kasper, Gabriele, \& Rose, Kenneth R. (2001). Pragmatics in language teaching. Ernst Klett Sprachen.

Lee, Cynthia. (2016). Understanding refusal style and pragmatic competence of teenage Cantonese English learners in refusals: An exploratory study. Intercultural Pragmatics, 13(2), 257-282.

Moafian, Fatemeh, Yazdi, Naji, \& Sarani, Abdullah. (2019). The refusal of request speech act in Persian, English, and Balouchi languages: A cross-cultural and crosslinguistic study. International Review of Applied Linguistics in Language Teaching, 1 (ahead-of-print).

Morkus, Nader. (2014). Refusals in Egyptian Arabic and American English. Journal of Pragmatics, 70, 86-107.

Musniati, Musniati. (2019). Cancelling and Refusal Strategy used by the Grab Driver of Lombok When Interacting with Customers. Fifth Prasasti International Seminar on Linguistics (PRASASTI 2019), 208-212. Atlantis Press.

Rubin, Joan. (1980). How to tell when someone is saying" no.". Research in Culture Learning: Language and Conceptual Studies. Honolulu: The University Press of Hawaii.

Searle, John R., \& Searle, John Rogers. (1977). Speech acts: An essay in the philosophy of language (Vol. 626). Cambridge university press.

Shishavan, Homa Babai, \& Sharifian, Farzad. (2016). The refusal speech act in a crosscultural perspective: A study of Iranian English-language learners and AngloAustralian speakers. Language \& Communication, 47, 75-88. 
The Strategies of Refusing Requests by Students of Different Ethnic Groups

Solihah, Rahmatillah, \& Imperiani, Ernie D. A. (2020). Refusal Strategies Among Sundanese Students: An Analysis of Gender and Power Relation. Twelfth Conference on Applied Linguistics (CONAPLIN 2019), 160-164. Atlantis Press.

$\mathrm{Su}$, Yunwen. (2020). Yes or no: Ostensible versus genuine refusals in Mandarin invitational and offering discourse. Journal of Pragmatics, 162, 1-16. 